\title{
蛭石-粘土系断熱材の強度などの性質に及ぼす 燐酸および燐酸塩添加の影響
}

\author{
椿隆 行* ・田 中 雅 美** \\ (*近畿大学理工学部応用化学科, **大阪府立大学工学部応用化学教室)
}

\begin{abstract}
Effect of Phosphoric Acid and Phosphate Additives on the Strength and Other Properties of Heat-Insu lators in the Vermiculite-Bond Clay System
\end{abstract}

\begin{abstract}
By
Takayuki TSUBAKI* and Masami TANAKA**

(*Department of Applied Chemistry, Kinki University, Osaka, **Department of Applied Chemistry, University of Osaka Prefecture, Osaka)

The reactivity of phosphoric acid and dihydrogen phosphate additives with expanded vermiculite aggregates and with bond clays at firing temperatures of $800^{\circ}$ and $1000^{\circ} \mathrm{C}$ was investigated from the measurements of $\mathrm{X}$-ray diffraction, water absorption and $\mathrm{pH}$ value. The aggregates were prepared by the calcination at $1050^{\circ} \mathrm{C}$ of the vermiculites from Fukushima Prefecture, Japan and from Palaboroa area, N. E. Transvaal, S. Africa. The bond clays were Mitsuishi-pyrophyllite from Okayama Prefecture and kibushi-clay from Aichi Prefecture. The effect of the additives on the compressive strength of fired insulators of the expanded vermiculite-bond clay system is discussed in connection with the above reactivity investigation. A remarkable increase in strength was observed when magnesium dihydrogen phosphate was added as an additive: The strength was about $22 \mathrm{~kg} / \mathrm{cm}^{2}$ for the test-specimens obtained by the firing at $1000^{\circ} \mathrm{C}$ of the mixture of 15 expanded vermiculite, 10 kibushi -clay and 75 pyrophyllite by wt $\%$, whereas the strength of about $39 \mathrm{~kg} / \mathrm{cm}^{2}$ was achieved when $1.5 \mathrm{wt} \%$ magnesium dihydrogen phosphate was added into the mixture. This is attributed to the formation of bridge bonds due to both reactions of magnesium dihydrogen phosphate with magnesium oxide component in vermiculites and with aluminum oxide component in bond clays. Little or no change in strength was observed when aluminum dihydrogen phosphate was added. This is connected with the $\mathrm{X}$-ray diffraction evidence that aluminum dihydrogen phosphate does not appreciably react with vermiculites though reacts with bond clays. The thermal conductivity shows a small decrease with increasing the content of additives. This corresponds to the porosity increase due to the dehydration condensation of the additives on firing.
\end{abstract}

[Received July 15, 1971]

\section{1. 緒言}

膨脹蛭石一粘土系断熱材の研究はかなり以前から行な われてきた・たとえば，Pence と Blount ${ }^{11}$ は蛭石ーテキ サス粘土系の軽量タイルへの応用, $\mathrm{Rea}^{2)}$ は蛭石ーベント ナイト系軽量構造材の製造, Hitner' ${ }^{3)}$ はベントナイトと カオリンを, Gitter $^{4)}$ はベントナイトと可塑性粘土をそ れぞれ結合材主成分とした蛭石質断熱材についての研 究, Robinson ${ }^{5}$ は比較的少量のパイロフィライトを含ま せカオリンを結合材主成分とした蛭石一粘土系の押出お よびプレス成型について試験研究などを行なっている. これらの結果から一般に望まれることは, 成型物の焼成
線収縮率 (3〜9\% の線収縮率) を減少させ, 強度の一層 の向上を図ることである.

著者らはさきに，蛭石一粘土系断熱材の結合材主成分 として蝋石を用い，木節粘土，ベントナイトおよび酸性 白土などの適量を副成分として加えることによって, 焼 成線収縮率を著しく減少させることができることを示し た（たとえば蝋石 75〜80，木節粘土 10, 蛭石 10１5 $\mathrm{wt} \%, 1000^{\circ} \mathrm{C}$ 焼成後の線収縮率 $\left.0.8 \sim 0.9 \%\right)^{6}$.

一方, 蛭石一粘土系断熱材の強度の向上を図るために, 珪酸塩類と比較的容易に反応する燐酸や燐酸塩類を結合 材副成分として加えた場合の影響をしらべることは興味 
があると考える。著者らが報告したように，オルト燐酸 二水素塩の加熱によって生成する結晶縮合燐酸塩の融点 は，金属カチオンのイオンポテンシャルの増大とともに 高くなり，マグネシウムやアルミニウムを含む塩の場合 には $1000^{\circ} \mathrm{C}$ 以上になる ${ }^{7}$. またこれらのカチオンを含 む非晶質固体の含水率は一般に小さい值をもっている.

これらのことから，蛭石一粘土系耐熱性断熱材に押ける 結合材副成分として燐酸, オルト燐酸二水素マグネシウ ムおよびオルト粼酸二水素アルミニウムを選び，それら の混合系の焼成性状小よび焼成物の強度や熱妘導率など におよぼす影響をしらべた。

\section{2. 実験}

\section{1 使用原料}

骨材として用いた膨脹蛭石は, 福島県小野新町産と, 南アフリカ連邦パラボラ産の蛭石原石とを粗研したの

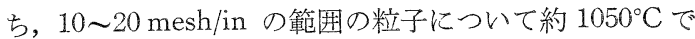
$1 / 2$ 分間焼成したものである. 結合材成分として使用し た粘土は，蟋石（岡山県和気郡三石町産）と木節粘土 （愛知県西加茂郡猿投町御船産）であるＸ線回折試験 に上れば，これらの粘土の主成分はそれぞれパイロフィ ライトとカオリナイトであり, ぞちらも少量の石英を含 んでいる ${ }^{6}$. 添加剤には $85 \%$ 燐酸（和光純薬工業（株）
試薬特級) ,オルト燐酸二水素アルミニムウ ((株) 多木製 肥所製）抒よびオルト燐酸二水素マグネシウム（島久薬 品（株）製）を用いた。

\section{2 試料の調製}

2.2.1 X線回折測定用試料 福島県産と南アフリカ 産の膨脹蛭石，絾石抒よび木節粘土の 4 種類の原料を， それぞれボールミルで約 $200 \mathrm{mesh} / \mathrm{in}$ に粉砕し，それぞ れの粉末を 3 個の坩堝に分けてとり, 燐酸, オルト燐酸 二水素アルミニウムおよびオルト燐酸二水素マグネシウ ムを，それぞれに $50 \mathrm{wt} \%$ ずつ添加したのち，さらに約 $20 \mathrm{~m} l$ の蒸留水を加えてよく混合した。 こ礼らの混合試 料を $110^{\circ} \mathrm{C}$ で乾燥したのち, $800^{\circ} \mathrm{C}$ と $1000^{\circ} \mathrm{C}$ で約 2 時間焼成し，瑪悩乳鉢で再び約 $200 \mathrm{mesh} / \mathrm{in}$ に粉砕した ものを測定に供した。

2.2 .2 吸湿性と $\mathrm{pH}$ の測定試料膨脹蛭石, 蜕石 および木節粘土の粉末 (約 $200 \mathrm{mesh} / \mathrm{in}$ ) を約 $3 \mathrm{~g}$ ずつ 磁製坩堝に分けてとり，適量（約 $50 \mathrm{~m} l$ の蒸留水を加え てよく混合したのち，粉末の乾燥重量 100 部に対して燐 酸を $0,1 ， 2 ， 5 ， 10 ， 20,50$ および 100 部加えて再び 充分混合する.この混合物を $110^{\circ} \mathrm{C}$ で 24 時間乾燥した 試料と，それをさらに $800^{\circ} \mathrm{C}$ で 4 時間焼成した試料か ら, 約 $2 \mathrm{~g}$ を吸湿性測定に, 残りの $1 \mathrm{~g}$ を $\mathrm{pH}$ 測定に 用いた。

Table 1. Weight ratio of components in mixing of heat-insulators in the vermiculite-bond clay-phosphoric acid and phosphate systems.

\begin{tabular}{|c|c|c|c|c|c|c|c|}
\hline Specimen No. & \multicolumn{2}{|c|}{$\begin{array}{l}\text { Aggregates } \\
\text { (Expanded vermiculite) }\end{array}$} & \multicolumn{2}{|c|}{ Bond clay } & \multicolumn{3}{|c|}{ Additives } \\
\hline & Fukushima & S. Africa & Kibushi-clay & Pyrophyllite & $\overparen{\mathrm{H}_{3} \mathrm{PO}_{4}}$ & $\mathrm{Al}\left(\mathrm{H}_{2} \mathrm{PO}_{4}\right)_{3}$ & $\mathrm{Mg}\left(\mathrm{H}_{2} \mathrm{PO}_{4}\right)_{2}$ \\
\hline $\mathrm{Vf} 1 \quad(\mathrm{Va} 1)$ & 40 & $(40)$ & 60 & & & & \\
\hline $\mathrm{Vf} 2 \quad(\mathrm{Va} 2)$ & 40 & $(40)$ & 60 & & 0.4 & & \\
\hline Vf $3 \quad(\mathrm{Va} 3)$ & 40 & $(40)$ & 60 & & 0.8 & & \\
\hline $\mathrm{Vf} \quad 4 \quad(\mathrm{Va} \quad 4)$ & 40 & $(40)$ & 60 & & 1.2 & & \\
\hline Vf $5 \quad(\mathrm{Va} 5)$ & 40 & $(40)$ & 60 & & 1.6 & & \\
\hline $\mathrm{Vf} \quad 6 \quad(\mathrm{Va} \quad 6)$ & 40 & (40) & 60 & & 2.0 & & \\
\hline Vf $7 \quad(\mathrm{Va} 7)$ & 40 & $(40)$ & 60 & & 4.0 & & \\
\hline Vf $8 \quad(\mathrm{Va} \quad 8)$ & 40 & $(40)$ & 60 & & 8.0 & & \\
\hline Vf $9 \quad(\mathrm{Va} 9)$ & 40 & $(40)$ & 60 & & 20.0 & & \\
\hline Vf $10 \quad(\mathrm{Va} 10)$ & 40 & $(40)$ & 60 & & & 0.4 & \\
\hline Vf $11 \quad$ (Va 11) & 40 & $(40)$ & 60 & & & 2.0 & \\
\hline Vf $12 \quad$ (Va 12) & 40 & $(40)$ & 60 & & & 4.0 & \\
\hline Vf $13 \quad$ (Va 13) & 40 & $(40)$ & 60 & & & & 0.4 \\
\hline Vf $14 \quad(\mathrm{Va} 14)$ & 40 & $(40)$ & 60 & & & & 2.0 \\
\hline Vf $15 \quad(\mathrm{Va} 15)$ & 40 & $(40)$ & 60 & & & & 4.0 \\
\hline Vf $16 \quad$ (Va 16) & 60 & $(60)$ & 40 & & & & \\
\hline Vf $17 \quad$ (Va 17) & 60 & $(60)$ & 40 & & 0.4 & & \\
\hline Vf 18 (Va 18) & 60 & $(60)$ & 40 & & 0.8 & & \\
\hline Vf 19 (Va 19) & 60 & $(60)$ & 40 & & 2.0 & & \\
\hline Vf $20 \quad($ Va 20$)$ & 60 & $(60)$ & 40 & & 4.0 & & \\
\hline Vf $21 \quad$ (Va 21) & 15 & (15) & 10 & 75 & & & \\
\hline Vf $22 \quad(\mathrm{Va} 22)$ & 15 & (15) & 10 & 75 & 0.15 & & \\
\hline Vf $23 \quad$ (Va 23) & 15 & (15) & 10 & 75 & 0.75 & & \\
\hline Vf $24 \quad(\mathrm{Va} 24)$ & 15 & (15) & 10 & 75 & 1.50 & & \\
\hline Vf $25 \quad(\mathrm{Va} 25)$ & 15 & (15) & 10 & 75 & & 0.15 & \\
\hline Vf $26 \quad(\mathrm{Va} 26)$ & 15 & (15) & 10 & 75 & & 0.75 & \\
\hline Vf $27 \quad$ (Va 27) & 15 & (15) & 10 & 75 & & 1.50 & \\
\hline Vf $28 \quad(\mathrm{Va} 28)$ & 15 & (15) & 10 & 75 & & & 0.15 \\
\hline Vf $29 \quad(\mathrm{Va} 29)$ & 15 & (15) & 10 & 75 & & & 0.75 \\
\hline Vf $30 \quad(\mathrm{Va} 30)$ & 15 & (15) & 10 & 75 & & & 1.50 \\
\hline
\end{tabular}


2.2.3 圧縮強さと熱伝導率測定用試料 圧縮強さと 熱伝導率測定に供した試料の成分配合比は 表-1 に示し た通りで亦る。試料番号の前につけた記号 Vfと Va は，それぞれ骨材として福島県産と南アフリカ産膨脹蛭 石を用いた試料であることを示している．結合材と骨材 の比は重量パーセント（wt％）で示した. また添加剤と しての燐酸をたは二水素燐酸塩は, 結合材と骨材の和に 対する重量パーセントで示してある。混練に要した水の 量は，JIS-R-2553 の水量決定法によって定めた. 配合 物の混練は，直径 $30 \mathrm{~cm}$ の金属製鉢沿骨材と結合材成 分を入れ，サジを用いて見掛上ほぼ均一な色調になるま で比較的静かに混合し，添加剂を加えてから一定量の水 を加えて約 5 分間比較的静かに混練する ${ }^{6}$.これらの配合 物を所定の 型枠に充填し，24 時間湿空中に放置したの ち離型（離型剤として流動パラフィンを使用）させ， $105^{\circ} \mathrm{C} \sim 110^{\circ} \mathrm{C}$ で 24 時間加熱して乾燥試料とした。この 乾燥試料を $800^{\circ} \mathrm{C}$ と $1000^{\circ} \mathrm{C}$ で各 4 時間焼成して, そ 剠ぞれ $800^{\circ} \mathrm{C}$ 焼成試料と $1000^{\circ} \mathrm{C}$ 焼成試料とした。な 抬これらの焼成に㧍ける昇温速度は $5^{\circ} \mathrm{C} / \mathrm{min}$ である。

\section{$2.3 \mathrm{X}$ 線回折測定}

理学電機 (株) 製のガイガーフレックス D-9 C を用 认，測定条件は $\mathrm{Cu} \mathrm{K}$ ，Ni-filter， $35 \mathrm{kV}-14 \mathrm{~mA}$ 打よ び Co $\mathrm{K}_{\alpha}, \mathrm{Fe}$-filter, $20 \mathrm{kV}-6 \mathrm{~mA}$ である. また角度範 囲は $60^{\circ} \sim 3^{\circ}$ ，スリットは 1-0.2-1, 走查速度は $1^{\circ} \% \mathrm{~min}$ である。

\section{4 吸湿性亡 $\mathrm{pH}$ の測定}

吸湿性は, 試料 (約 $2 \mathrm{~g}$ ) を粉砕した直後に秤量し, 1 週間湿空中で放置したのち再び秤量してその重量増加 （wt\%）として表わした.

また試料（約 $1 \mathrm{~g}$ ) を瑪悩乳鉢で粉砕（約 200 meshes /in)したのち秤量してエルレンマイヤー・フラスコに入 れ, 試料 $1 \mathrm{~g}$ に対して $50 \mathrm{~m} l$ の割合で蒸留水を加え, 1 日数回の擋拌操作を加えて 1 週間室温保ったのち, 水溶液について $\mathrm{pH}$ を測定して試料の $\mathrm{pH}$ とした。 こ の測定には日立-堀場製 $\mathrm{M}-5$ 型 $\mathrm{pH}$ メーターを使用し た.

\section{5 圧縮強さの測定}

スプリング・テスター（測定最大荷重 100，200 およ び $500 \mathrm{~kg}$ ）を用い, 直径 $2.5 \mathrm{~cm}$, 高さ $2.5 \mathrm{~cm}$ の円柱 形試料について圧縮強さの測定を行なった，荷重速度は $7 \sim 8 \mathrm{~kg} / \mathrm{cm}^{2} / \mathrm{sec}$ である. 各試料とも 9 個の供試体につ いて得られた結果の平均值とその確率誤差範囲を求め た.

\section{6 熱伝導率の測定}

比較法による熱伝導率測定装置 ${ }^{6)}$ を用いた. 熱伝導率 既知の珪藻土標準板（縦,横㐨よび高さ，それぞれ 19.0， 19.0 㧍よび $2.0 \mathrm{~cm}) 2$ 枚と, 同形同大の測定試料 2 枚

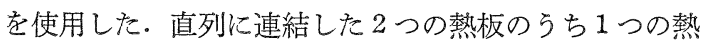

板の上下に標準板を，他の熱板の上下に測定試料を充填 し，適当な定電流を通じて定常状態に達したのち（約 5 時間後), $60^{\circ} \sim 170^{\circ} \mathrm{C}$ の範囲内の平均温度における熱伝 導率を測定した。ここで平均温度とは測定試料の熱面温 度と泠面温度の平均值である。

\section{3. 結果亡考察}

\section{$3.1 \mathrm{X}$ 線回折}

福島県産と南アフリカ産の膨脹蛭石, 蝉石および木節 粘土のそれぞれの粉末に燐酸を添加混練し，800～1000 ${ }^{\circ} \mathrm{C}$ で約 2 時間焼成した試料のX線回折図の数例を 図-1 に示す.このような回折図に見いだされたピークに対応 する主な結晶について,ASTM の X-ray Powder Diffraction File を用いて同定し結果を表-2（a）に示す.こ の表加らかるように，蛭石と燐酸を $800^{\circ} \sim 1000^{\circ} \mathrm{C}$ で 焼成するとオルト燐酸マグネシウム結晶が生成し，蝟石

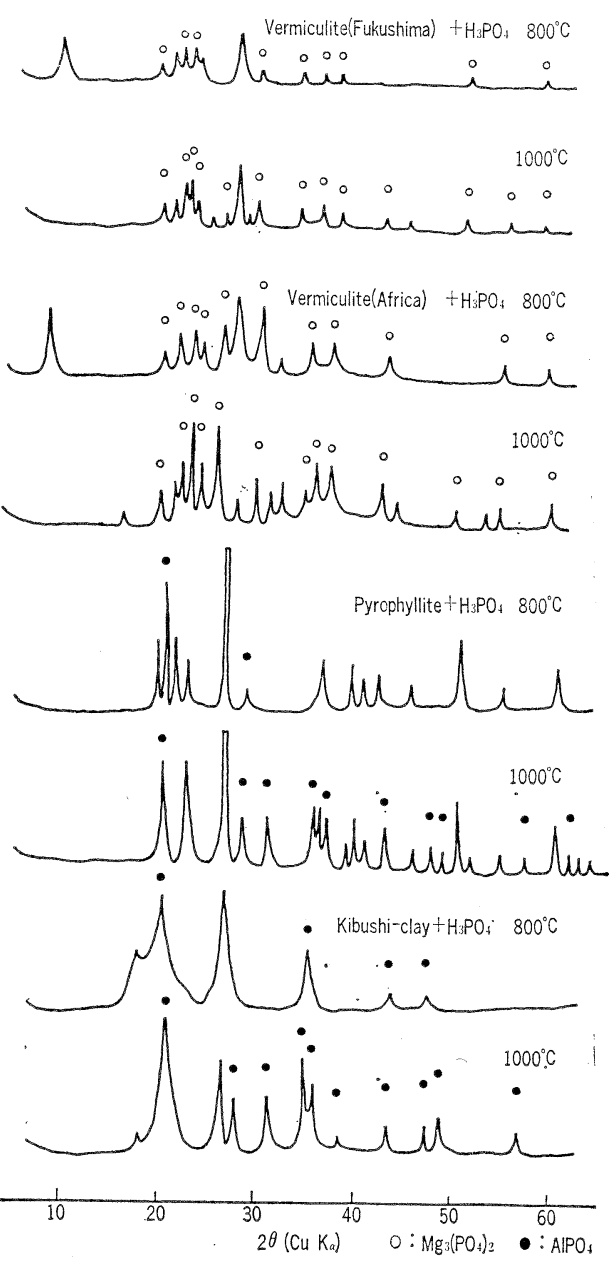

Fig. 1. X-ray diffraction patterns of phosphoric acid with vermiculite aggregates and with bond clays at firing temperatures of $800^{\circ}$ and $1000^{\circ} \mathrm{C}$. 
Table 2. Crystalline substances identified by X-ray diffraction.

\begin{tabular}{|c|c|c|c|c|}
\hline \multirow{2}{*}{$\begin{array}{l}\text { Powder } \\
\text { specimens }\end{array}$} & \multirow{2}{*}{$\begin{array}{l}\text { Firing } \\
\text { temperatures }\left({ }^{\circ} \mathrm{C}\right)\end{array}$} & \multicolumn{3}{|c|}{ Additives } \\
\hline & & $\begin{array}{c}(\mathrm{a}) \\
\mathrm{H}_{3} \mathrm{PO}_{4}\end{array}$ & $\begin{array}{c}(\mathrm{b}) \\
\mathrm{Mg}\left(\mathrm{H}_{2} \mathrm{PO}_{4}\right)_{2}\end{array}$ & $\begin{array}{c}(\mathrm{c}) \\
\mathrm{Al}\left(\mathrm{H}_{2} \mathrm{PO}_{4}\right)_{3}\end{array}$ \\
\hline \multirow{2}{*}{$\begin{array}{l}\text { Expanded } \\
\text { vermiculite } \\
\text { Fukushima }\end{array}$} & 800 & $\mathrm{Mg}_{3}\left(\mathrm{PO}_{4}\right)_{2}$ & $\mathrm{Mg}_{3}\left(\mathrm{PO}_{4}\right)_{2}$ & $\mathrm{AlPO}_{4}$ \\
\hline & 1000 & $\mathrm{Mg}_{3}\left(\mathrm{PO}_{4}\right)_{2}$ & $\mathrm{Mg}_{3}\left(\mathrm{PO}_{4}\right)_{2}$ & $\mathrm{AlPO}_{4}$ \\
\hline \multirow{2}{*}{$\begin{array}{l}\text { Expanded } \\
\text { vermiculite } \\
\text { S. Africa }\end{array}$} & 800 & $\mathrm{Mg}_{3}\left(\mathrm{PO}_{4}\right)_{2}$ & $\mathrm{Mg}_{3}\left(\mathrm{PO}_{4}\right)_{2}+\left(\mathrm{Mg}_{2} \mathrm{P}_{2} \mathrm{O}_{7}\right)$ & $\mathrm{Mg}_{3}\left(\mathrm{PO}_{4}\right)_{2}+\left(\mathrm{AIPO}_{4}\right)$ \\
\hline & 1000 & $\mathrm{Mg}_{3}\left(\mathrm{PO}_{4}\right)_{2}$ & $\mathrm{Mg}_{3}\left(\mathrm{PO}_{4}\right)_{2}+\left(\mathrm{Mg}_{2} \mathrm{P}_{2} \mathrm{O}_{7}\right)$ & $\mathrm{Mg}_{3}\left(\mathrm{PO}_{4}\right)_{2}+\left(\mathrm{AlPO}_{4}\right)$ \\
\hline \multirow{2}{*}{ Pyrophyllite } & 800 & $\mathrm{AlPO}_{4}$ & $\mathrm{Mg}_{2} \mathrm{P}_{2} \mathrm{O}_{7}+\left(\mathrm{AlPO}_{4}\right)$ & $\mathrm{AlPO}_{4}$ \\
\hline & 1000 & $\mathrm{AlPO}_{4}$ & $\mathrm{Mg}_{2} \mathrm{P}_{2} \mathrm{O}_{7}+\mathrm{AlPO}_{4}$ & $\mathrm{AlPO}_{4}$ \\
\hline \multirow{2}{*}{ Kibushi-clay } & 800 & $\mathrm{AlPO}_{4}$ & $\mathrm{Mg}_{2} \mathrm{P}_{2} \mathrm{O}_{7}+\left(\mathrm{AlPO}_{4}\right)$ & $\mathrm{AlPO}_{4}$ \\
\hline & 1000 & $\mathrm{AlPO}_{4}$ & $\mathrm{Mg}_{2} \mathrm{P}_{2} \mathrm{O}_{7}+\mathrm{AlPO}_{4}$ & $\mathrm{AlPO}_{4}$ \\
\hline
\end{tabular}

や木節粘土と憐酸とをとの温度域で焼成すると，オルト 燐酸アルミニウム結晶が生成する。こ机らの結果は, 蛭 石中のマグネシウム成分や粘土中のアルミニウム成分と 燐酸の反応によるものである。充た，図-1の数例から も認的られるように，南アフリカ産蛭石一燐酸系焼成物 の方が，福島県産蛭石一燐酸系燒成物よりもオルト燐酸 マグネシウム結晶のピークがやや顕著であり，その結晶 生成量はやや多いといえる。これは南アフリカ産蛭石中 のマグネシウム含量 $(\mathrm{MgO}$ として 21.9\%) が福島県 産蛭石 $(\mathrm{MgO}$ として 7.8\%) よりも多いことと関係し ていると考えられる8

つぎに燐酸のかわりにオルト燐酸二水素マグネシウム 意蛭石や粘土類に添加混練し， $800^{\circ} \mathrm{C}$ 㧍上び $1000^{\circ} \mathrm{C}$ で 約 2 時間焼成したものについて同様の測定を行なった。 その結果安図 -2 (測定の数例) と表-2（b）に示す. 福
島県産蛭石一オルト燐酸二水素マグネシウム系の場合は, $800^{\circ} \sim 1000^{\circ} \mathrm{C}$ の焼成でオルト燐酸マグネシウム結晶が 主として生成し, 南アフリカ産蛭石の場合は同じ条件で オルト燐酸マグネシウムのほかにピロ燐酸マグネシウム 結晶が生成している。蛢石一オルト燐酸二水素マグネシ ウム系と木節粘土一オルト燐酸二水素マグネシウム系で は, $800^{\circ} \sim 1000^{\circ} \mathrm{C}$ 焼成で生成が認好られる結晶は, 主と してピロ燐酸マグネシウム晾よびオルト燐酸アルミニウ ムである.

また，オル卜燐酸二水素アルミニウムを蛭石や粘土類 に添加混練し，上記と同じ条件で焼成したときの結果索 図-3 と表-2 (c) に示す. 南アフリカ産蛭石一オル卜橉 酸二水素アルミニウム系については， $800^{\circ} \sim 1000^{\circ} \mathrm{C}$ で 焼成した場合，オルト燐酸マグネシウムおよびオルト燐 酸アルミニウムの結晶が主として生成するが，福島県産

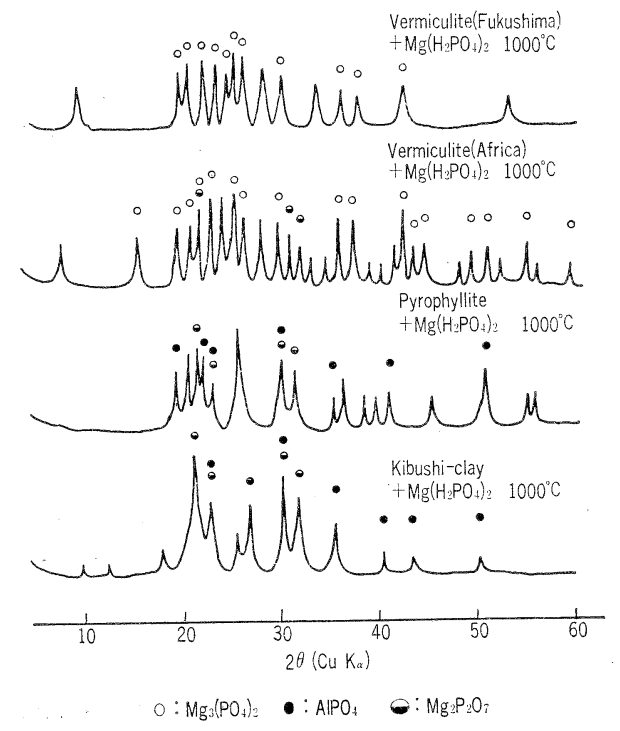

Fig. 2. X-ray diffraction patterns of magnesium dihydrogen phosphate with vermiculite aggregates and with bond clays at firing temperature of $1000^{\circ} \mathrm{C}$.

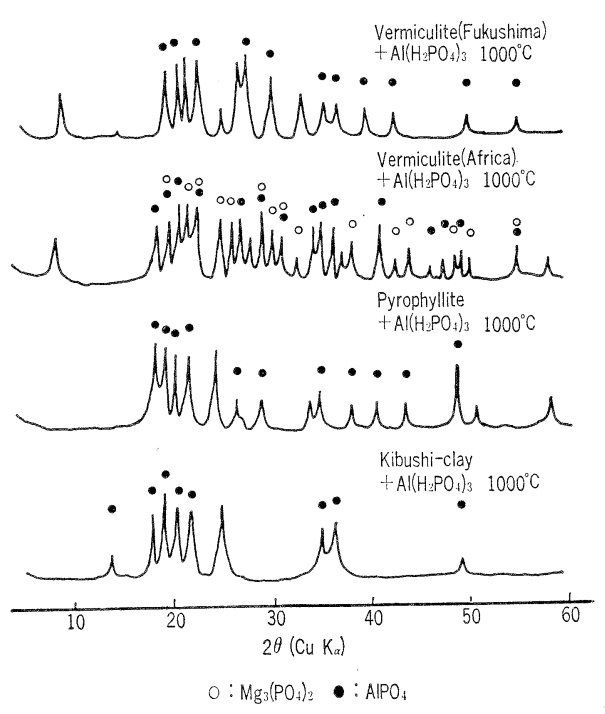

Fig. 3. X-ray diffraction patterns of aluminum dihydrogen phosphate with vermiculite aggregates and with bond clays at firing temperature of $1000^{\circ} \mathrm{C}$. 
蛭石，蝋石および木節粘土の場合は $800^{\circ} \sim 1000^{\circ} \mathrm{C}$ 焼成 で主として生成する結晶相はすべてオルト燐酸アルミニ ウムであった。

以上はすべて結晶相として生成することがX線的に認 められた燐酸塩であるが，これらのほかに，燐酸添加の 際にはその脱水縮合によって五酸化燐が，非晶質相とし て生成していることもじゅうぶん考えられる。

つぎに，上に述べた燐酸塩が，各原料と添加剤との反 応によって生成される過程について検討する。まず，蛭 石に粼酸を添加したときにオルト燐酸マグネシウムが生 成する過程としては, 蛭石中のマグネシウム成分が反応 に関与し得るとしてつぎの (1)，(2) および（3）が 考えられる。

$$
\begin{aligned}
& 2 \mathrm{H}_{3} \mathrm{PO}_{4} \stackrel{\text { 加熱 }}{\longrightarrow} \mathrm{P}_{2} \mathrm{O}_{5}+3 \mathrm{H}_{2} \mathrm{O} \\
& \mathrm{P}_{2} \mathrm{O}_{5}+3 \mathrm{MgO} \text { (蛭石中) } \rightarrow \mathrm{Mg}_{3}\left(\mathrm{PO}_{4}\right)_{2}
\end{aligned}
$$

㐫るいは（1）と（2）が同時に起る反応として

$$
3 \mathrm{MgO}+2 \mathrm{H}_{3} \mathrm{PO}_{4} \rightarrow \mathrm{Mg}_{3}\left(\mathrm{PO}_{4}\right)_{2}+3 \mathrm{H}_{2} \mathrm{O} \cdots \cdots \text { (3) }
$$

また，蝋石や木節粘土に燐酸を添加した場合は，これら に含まれるアルミニウム成分が反応し得るとすれば，酸 化アルミニウムと粼酸からオルト橉酸アルミニウムがで きる過程として知られている，つぎの（4）掠よび（5) の反応 ${ }^{9}$ によってオルト燐酸アルミニウムが生成すると 考えることができる。

$$
2 \mathrm{H}_{3} \mathrm{PO}_{4} \rightarrow \mathrm{H}_{4} \mathrm{P}_{2} \mathrm{O}_{7}+\mathrm{H}_{2} \mathrm{O}
$$

$\mathrm{Al}_{2} \mathrm{O}_{3}$ (粘土中) $+\mathrm{H}_{4} \mathrm{P}_{2} \mathrm{O}_{7} \rightarrow 2 \mathrm{AlPO}_{4}+2 \mathrm{H}_{2} \mathrm{O} \cdots$ (5)

つぎに，オルト燐酸二水素マグネシウムを添加した場 合について考える。燐酸添加の場合と同様に蛭石中のマ グネシウム成分が反応に関与し得るとすると，オルト燐 酸マグネシウムおよびピ口燐酸マグネシウムが生成する 過程としてつぎの (6)，(7) おおよ゙（8）が考光られ る.

$$
\begin{aligned}
& \mathrm{Mg}\left(\mathrm{H}_{2} \mathrm{PO}_{4}\right)_{2} \rightarrow \mathrm{Mg}\left(\mathrm{PO}_{3}\right)_{2}+2 \mathrm{H}_{2} \mathrm{O} \\
& \mathrm{Mg}\left(\mathrm{PO}_{3}\right)_{2}+\mathrm{MgO} \rightarrow \mathrm{Mg}_{2} \mathrm{P}_{2} \mathrm{O}_{7} \ldots \ldots \\
& \mathrm{Mg}\left(\mathrm{PO}_{3}\right)_{2}+2 \mathrm{MgO} \rightarrow \mathrm{Mg}_{3}\left(\mathrm{PO}_{4}\right)_{2}
\end{aligned}
$$

ピロ燐酸マグネシウム生成過程としては，Lyon $ら^{10)}$ が 酸化マグネシウム耐火物の結合材に燐酸塩を用いる効果 についての報告で述べている，つぎの反応がここでもお こる可能性がある.

$\mathrm{Mg}\left(\mathrm{H}_{2} \mathrm{PO}_{4}\right)_{2}+\mathrm{MgO} \rightarrow 2 \mathrm{MgHPO}_{4}$

$2 \mathrm{MgHPO}_{4} \rightarrow \mathrm{Mg}_{2} \mathrm{P}_{2} \mathrm{O}_{7}+\mathrm{H}_{2} \mathrm{O}$

ただし, 福島県産蛭石ではオルト粼酸マグネシウム結晶 のみが認められ，南アフリカ産蛭石ではこのほかにピロ 燐酸マグネシウム結晶もともに認められている.この差 異は，マグネシウム成分の多い南アフリカ産蛭石の場合 に上記の（7）あるいは（9)，(10）の反応が福島県蛭 石の場合上りも進行するためであるかも知れないが，本 研究の実験結果だけでは不明である。また，蝋石あるい は木節粘土とオルト燐酸二水素マグネシウム系の場合に
いずれもピロ燐酸マグネシウム結晶とオルト燐酸アルミ ニウム結晶の生成が認められたが，この変化の過程も， これらの粘土中に含まれるアルミニウム成分が酸化アル ミニウムの形で反応に関与する場合にはつぎのように考 えられる。

$$
\begin{aligned}
& 2 \mathrm{Mg}\left(\mathrm{H}_{2} \mathrm{PO}_{4}\right)_{2}+\mathrm{Al}_{2} \mathrm{O}_{3} \rightarrow \\
& \quad \mathrm{Mg}_{2} \mathrm{P}_{2} \mathrm{O}_{7}+2 \mathrm{AlPO}_{4}+4 \mathrm{H}_{2} \mathrm{O} \cdots
\end{aligned}
$$

あるいは (6) でできた $\mathrm{Mg}\left(\mathrm{PO}_{3}\right)_{2}$ と

$$
2 \mathrm{Mg}\left(\mathrm{PO}_{3}\right)_{2}+\mathrm{Al}_{2} \mathrm{O}_{3} \rightarrow 2 \mathrm{AlPO}_{4}+\mathrm{Mg}_{2} \mathrm{P}_{2} \mathrm{O}_{7} .
$$

最後に，オルト燐酸二水素アルミニウムを添加した場 合について考える・オルト燐酸二水素アルミニウムは加 熱により脱水縮合し， $500^{\circ} \mathrm{C}$ 以上ではメ夕燐酸アルミニ ウムが主成分になる ${ }^{11}$ 。しかし，さらに温度が上がって $800^{\circ} \mathrm{C}$ 以上になると五酸化橉の揮散に伴。て生成する結 晶性のオルト燐酸アルミニウムが増加することが報告さ れている ${ }^{12)}$. 蛭石にオルト燐酸二水素アルミニウムを添 加した系を焼成した試料中に認められたオルト燐酸アル ミニウム結晶は，この過程で生成したとも考えられる。 しかし粘土類とオルト燐酸二水素アルミニウムの系にお けるオルト燐酸アルミニウムの生成には, 他の添加剤の 場合と同様に粘土中のアルミニウム成分が反応に関与す るとすれば

$$
\begin{aligned}
& \mathrm{Al}\left(\mathrm{H}_{2} \mathrm{PO}_{4}\right)_{3} \rightarrow \mathrm{Al}\left(\mathrm{PO}_{3}\right)_{3}+3 \mathrm{H}_{2} \mathrm{O} \\
& \mathrm{Al}\left(\mathrm{PO}_{3}\right)_{3}+\mathrm{Al}_{2} \mathrm{O}_{3} \rightarrow 3 \mathrm{AlPO}_{4} \cdots .
\end{aligned}
$$

の過程む考えられる. ここで, 南アフリカ産蛭石一オル 卜燐酸二水素アルミニウム系の場合だけオルト燐酸マグ ネシウムの結晶相の生成が認められた。福島県産蛭石に 比較してマグネシウム成分の多い南アフリカ産蛭石の場 合にオルト燐酸マグネシウム結晶相が生成した過程とし ては，(13)で生じたメタ燐酸アルミニウムと南アフリカ 産蛭石中のマグネシウム成分が酸化マグネシウムとして (15) 式のように反応し,

$$
\mathrm{Al}\left(\mathrm{PO}_{3}\right)_{3}+3 \mathrm{MgO} \rightarrow \mathrm{Mg}_{3}\left(\mathrm{PO}_{4}\right)_{2}+\mathrm{AlPO}_{4} \cdots
$$

連結している- $\mathrm{PO}_{3}$ 一骨格が切れていってアルミニウムお よびマグネシウムのそれぞれのオルト燐酸塩を生成する 過程も考えられる。オルト燐酸二水素マグネシウム拉よ びオルト燐酸二水素アルミニウムを添加した場合には， これらの二水素塩自身の脱水縮合によって $\mathrm{Mg}\left(\mathrm{PO}_{3}\right)_{2}$ および $\mathrm{Al}\left(\mathrm{PO}_{3}\right)_{3}$ の組成で表わされるメ夕燐酸塩が生成 することはじゅうぶん考えられる、したがって，これら の二水素塩を添加した系で認められたピロ燐酸マグネシ ウム，オルト燐酸マグネシウム拉よびオルト燐酸アルミ ニウムは，>夕橉酸塩から五酸化燐が揮散することによ っても生成可能であり, 前記, 諸過程と平行しておこっ ているはずである。しかし，本研究の焼成条件ではこの 過程の寄与は少ないと考えるべきであるう。

また，これらのメタ燐酸塩の融点はいずれも $1000^{\circ} \mathrm{C}$ 以上であり，焼成温度が最高 $1000^{\circ} \mathrm{C}$ であったことから 
すべてがガラス状態として生成しているとは考え難い。 X線回折結果に，これらのメタ燐酸塩結晶によるピーク がはっきり現われなかったことは，蛭石や蝋石あるいは 木節粘土中のマグネシウムおよびアルミニウムの酸化物 成分が関与する（7)，（8)，(11)，(12)，(14）および

(15）の過程がかなり抽りやすいか，あるいは二水素 塩と金属酸化物成分との反応で一挙にピロ粼酸マグネシ ウム，オルト燐酸マグネシウムあるいはオルト燐酸アル ミニウムを生成するのではないかといらことを示唆して いる.

（1）〜（15）の反応は，可能性を考慮した上で推定し た過程であるが，本研究の範囲では確かな断定をさけた い.しかし，ここで述べたよらに，添加剤と原料中の成 分との間に反応がおこっていることはじゅらぶん考えら れるし，それはまた原料粒子の界面における固相反応と して扢っていると見ることができる。これらの考察結 果は 3.3 で述べる圧縮強さに現われる効果を説明するた めの基礎となるものである。なお，蛭石や粘土類に燐酸 塩を 5 wt\% ずつ添加した場合の $800^{\circ} \mathrm{C}$ と $1000^{\circ} \mathrm{C}$ 焼 成試料の X 線回折結果も，図-1，2，3 および表-2 に示 したものと同じ生成物が少量ではあるがす心゙て認められ た.

\section{2 吸湿性と $\mathrm{pH}$}

膨脹蛭石, 蟬石および木節粘土それでれの 100 部に対 して燐酸を $0 \sim 100$ 部加えた混合系の $110^{\circ} \mathrm{C}$ 乾燥試料 と $800^{\circ} \mathrm{C}$ 焼成試料について吸湿性と $\mathrm{pH}$ を測定した. これらの試料の吸湿性と燐酸添加量（wt％）との関係を 図-4 に示す. 各系とも $800^{\circ} \mathrm{C}$ 燒成試料は, $110^{\circ} \mathrm{C}$ 乾燥 試料より 吸湿性が減少している。これは，3.1 で述べ たように，燒成によって燐酸が膨脹蛭石や粘土中のマグ ネシウムやアルミニウム成分と反応して，吸湿性である 遊離燐酸成分の混在量が減少したためと考えられる.

図-5 は試料の $\mathrm{pH}$ と燐酸添加量の関係を示したもの である。各混合系の $\mathrm{pH}$ の変化のようすや，その範囲に は相違が見られる。しかし各混合系に共通した 2 つの傾 向を認めることができる，その1つは，混合系の燐酸量 が増大すると，その $110^{\circ} \mathrm{C}$ 乾燥試料の $\mathrm{pH}$ が減少する 傾向である：これは乾燥試料中に含まれる燐酸成分の増 大によるといえる。他の 1 つは $800^{\circ} \mathrm{C}$ 焼成試料の場合 であって，混合系中の燐酸量 $10 \mathrm{wt} \%$ 付近までは焼成試 料の $\mathrm{pH}$ は増大するか，またはほとんど変化しないが， 燐酸量がそれより増大すると $\mathrm{pH}$ は減少する傾向があ る、これは混合系中の約 $10 \mathrm{wt} \%$ までの燐酸のほとんど が燐酸マグネシウムや燐酸アルミニウム結晶の生成に消 費されでおり，燐酸添加量がそれ以上になると，焼成物 中に遊離の無水燐酸に近い成分が混在してくるためであ ると考えられる。

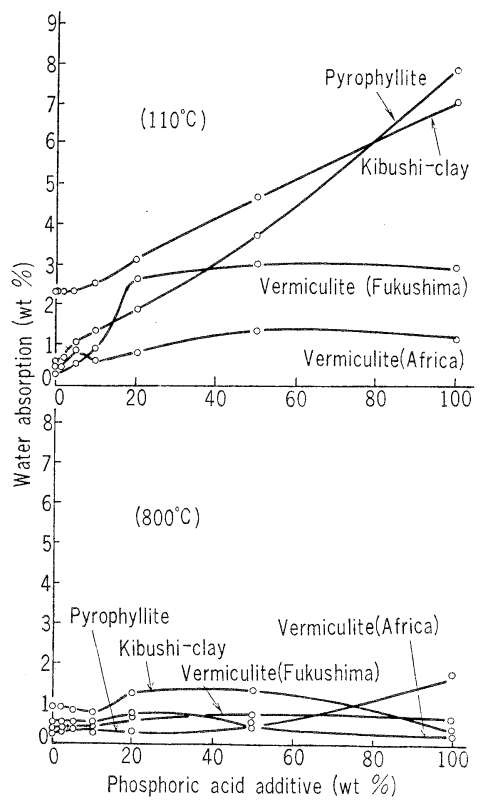

Fig. 4. Relation between phosphoric acid additive (wt $\%$ ) and water absorption in the vermiculites and bond-clays at drying temperature of $110^{\circ} \mathrm{C}$ and firing temperature of $800^{\circ} \mathrm{C}$.

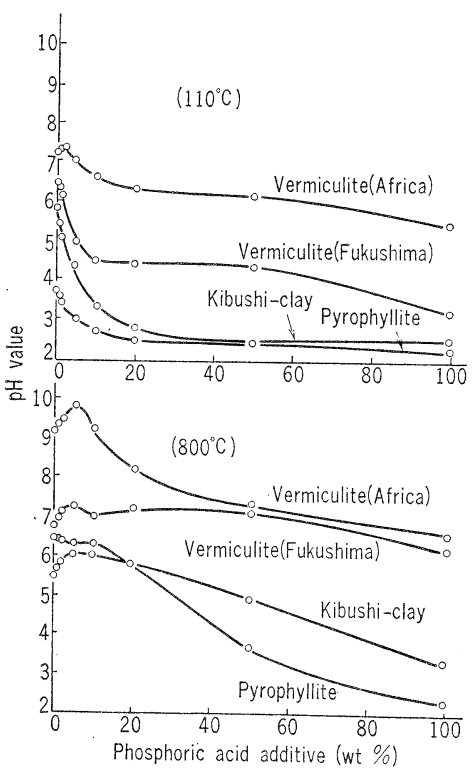

Fig. 5. Relation between phosphoric acid additive (wt $\%$ ) and $\mathrm{pH}$ value in the vermiculites and bond clays at drying temperature of $110^{\circ} \mathrm{C}$ and firing temperature of $800^{\circ} \mathrm{C}$.

\section{3 圧縮強さ}

膨脹蛭石, 蟬石および木節粘土と, 燐酸や燐酸塩との 混合系の燒成による $\mathrm{Al}_{2} \mathrm{O}_{3}-\mathrm{P}_{2} \mathrm{O}_{5}$ 系や $\mathrm{MgO}-\mathrm{P}_{2} \mathrm{O}_{5}$ 系結 晶の生成が，蛭石一粘土系断熱材における結合材内部や， 骨材一結合材間の結合力と関係をもつならば,その断熱材 のバルクな性質としての強さにも影響を与えることが考 

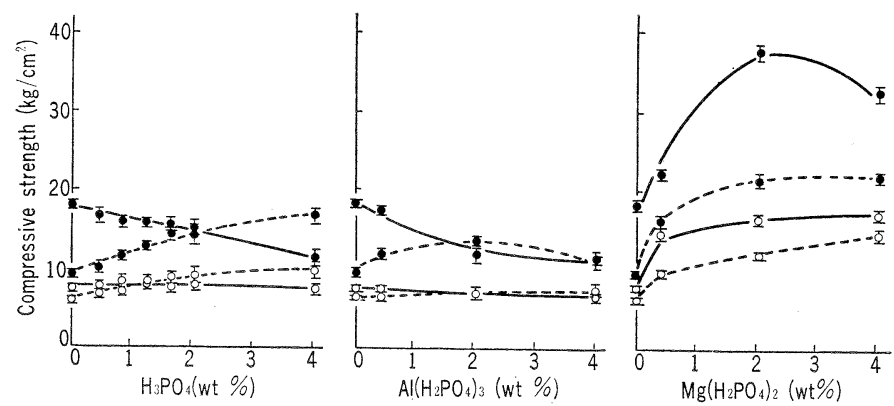

포 : $110^{\circ} \mathrm{C}$

9: $800^{\circ} \mathrm{C}$

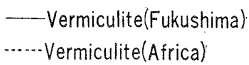

Fig. 6. Effect of additives on the compressive strength of heat insulators in the expanded vermiculite-kibushi clay system.
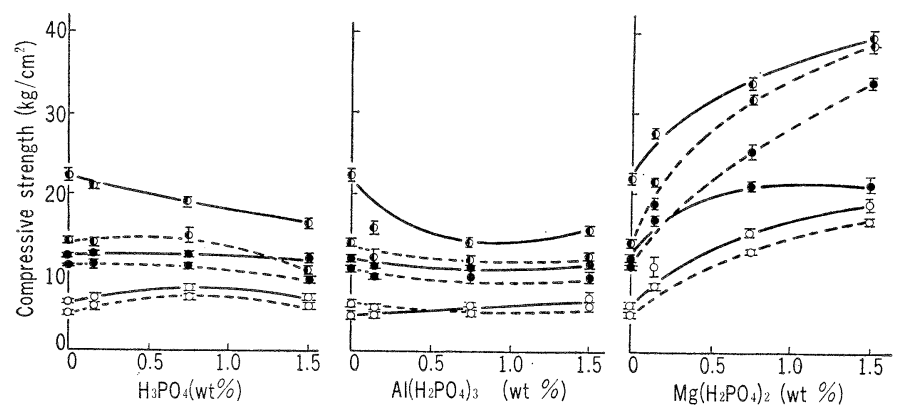

$$
\begin{aligned}
& \text { ㅎ: } 110^{\circ} \mathrm{C} \quad \Phi: 800^{\circ} \mathrm{C} \quad \Phi: 1000^{\circ} \mathrm{C} \\
& \text {-Vermiculite(Fukushima) …...Vermiculite(Africa) }
\end{aligned}
$$

Fig. 7. Effect of additives on the compressive strength of heat insulators in the expanded vermiculite-pyrophyllite-kibushi clay system.

えられる，そこで，表-1 に記載した配合組成のものか ら，2.2.3で述べた方法によって調製した乾燥試料抢よ び焼成試料について,圧縮強さを測定した結果に基づき， この性質におよぼす燐酸あるいは燐酸塩添加の影響につ いて考察した。

種々の組成をもつ配合試料と，これに0〜4 wt\% の燐 酸, オルト燐酸二水素マグネシウムおよびオルト燐酸二 水素アルミニウムのうち 1 種を添加して $110^{\circ} \mathrm{C}$ で乾燥 した試料, $800^{\circ} \mathrm{C}$ および $1000^{\circ} \mathrm{C}$ で焼成した試料の圧縮 強さ $\left(\mathrm{kg} / \mathrm{cm}^{2}\right)$ と添加量 $(\mathrm{wt} \%)$ との関係を図-6 (表-1 のVf 1〜7, Vf 10〜15, Va 1〜7 および Va 10〜15) および図-7 (表-1 のVf 21〜30 およびVa 21〜30) に示した。これらの図中の各点は測定值の確率誤差範团 を示した。

圧縮強さの測定結果にはつぎのような特徵が認められ る.オルト燐酸二水素マグネシウムを添加した試料につ いては，その添加量の増加とともに圧縮強さの増大する 傾向がすべての試料について認められる。しかし，オル 卜燐酸二水素アルミニウム添加試料では, 特にめだった
強度変化が認められない。また燐酸添加の 場合は，試料に用いた原料蛭石の種類や調 製条件などにより，圧縮強さに現われる影 響に多少の相違が認められる程 度であっ た．そこで各原料と添加鼡との反応生成物 のX線回折による同定結果 (表-2) と，3. 1 で述べた生成過程に対する推論とに基づ いて，それぞれの添加剤が圧縮強さに与え る効果について検討してみよう.

まず，いちように圧縮強さが増大したオ ルト燐酸二水素マグネシウム添加の場合に ついて考える．表-2 に示したとおり，骨 材㧍よび結合材の各成分とオルト燐酸二水 素マグネシウムとの反応生成物には共通し て $\mathrm{MgO}-\mathrm{P}_{2} \mathrm{O}_{5}$ 系結晶相の存在が認められ た. 3.1 で述べたよらに, 蛭石中のマグネ シウム成分が, この結晶相の生成過程に関 与していると考えられる。また，蝉石ある いは木節粘土の中のアルミニウム成分も， (11) あるいは (12) の反応でピロ燐酸マ グネシウムおよびオルト燐酸アルミニウム の生成に関与していると考えれば，骨材と しての蛭石粒子や結合材としての蝋石ある いは木節粘土粒子の間に上記の反応生成物 が介在し，各粒子の界面で接着層を形成し て強度を増大させる効果を与光ると考えら れる。

つぎに, オルト燐酸二水素アルミニウム を添加した場合について検討する：この場 合は図 -5 および図-6 からわかるよらに添加剤の量に対 する圧縮強さの変化はほとんど認められない，表-2（c) に示したように，ここで考えられる生成物は南アフリカ 産蛭石の場合を除いてすべてオルト燐酸アルミニウムで ある、このことは，結合材中のアルミニウム成分が添加 剂と（14）式のように反応して界面にオルト燐酸アルミ ニウム層を生成するが，福島県産蛭石一オルト燐酸二水 素アルミニウム系で $\mathrm{MgO}-\mathrm{P}_{2} \mathrm{O}_{5}$ 系結晶相の生成が認め られないことから，福島県産蛭石中のマグネシウム成分 とオルト燐酸二水素アルミニウム（あるいはメ夕燐酸ア ルミニウム）との反応はほとんど進まず，したがって骨 材の界面での接着層が形成されないために圧縮強さを増 大するに至らなかったものと思われる. 南アフリカ産蛭 石一木節粘土一オルト燐酸二水素アルミニウム系の 800 ${ }^{\circ} \mathrm{C}$ 焼成試料の圧縮強さにわずかながら変化が認められ るのは, 南アフリカ産蛭石中のマグネシウム成分が比較 的多いので表-2 (c) にも示したように，(15)式によって オルト燐酸マグネシウムを生じ，それによって骨材表面 である程度接着層が形成されたためと考えられる．南ア 
フリカ産蛭石一蛕石一木節粘土一オルト憐酸二水素アル ミニウム系で全く圧縮強さに変化が認められないのは, 南アフリカ産蛭石一木節粘土一オルト燐酸二水素アルミ ニウム系の場合と比較して, 南アフリカ産蛭石の配合比 が $1 / 2$ 以下であり，オルト燐酸二水素アルミニウムの添 加量も少ないため, 骨材表面で接着層を形成するに至ら なかったものと思われる。

以上のことを総合すると，つぎのようにいえる，蛭石 一粘土系に添加剤としてオルト燐酸二水素マグネシウム を加えて焼成すると，添加剤が蛭石骨材抒よび粘土結合 材中の金属酸化物成分と反応して, $\mathrm{MgO}-\mathrm{P}_{2} \mathrm{O}_{5}$ 系や $\mathrm{Al}_{2} \mathrm{O}_{3}-\mathrm{P}_{2} \mathrm{O}_{5}$ 系の結晶をマトリックス中に生成し, それ が骨材と結合材の両者の界面において接着層を形成する ことによって，そのマトリックスの圧縮強さを増大させ る効果を与える、したがって, オルト燐酸二水素アルミ ニウム添加の場合のように蛭石骨材との反応性が不十分 なときは,この効果が現われないと考えることができる.

燐酸添加の場合は, 骨材や結合材のそれぞれの表面で は表-2 (a) に示される結晶相が生成するが，オルト燐酸 二水素マグネシウム添加のときのような骨材粒子と結合 材粒子の接着を強化する媒介物としての効果を示すには 至らないようである。ただし，南アフリカ産蛭石一木節 粘土一燐酸系の $800^{\circ} \mathrm{C}$ 焼成試料沶いて, 燐酸添加量 の増加に伴って，わずかに圧縮強さの上昇が認められた のは, 南アフリカ産蛭石中にマグネシウム成分が多いた め，オルト燐酸マグネシウムの生成量が福島県産蛭石の 場合より多く, 結合強化の効果が多少現われたものかも 知孔ない.

\section{4 熱伝導率}

表-1 に記載した福島県産 膨脹蛭石 (60)一木節粘土 （40）の基礎組成をもつ配合物（Vf 16）と，これ燐 酸を $4 \mathrm{wt} \%$ 添加した配合物（Vf 20）および同表に示 した南アフリカ産膨脹蛭石 (40)一木節粘土 (60) の基礎 組成をもつ配合物（Va 1) と，これに燐酸をたはオル卜 燐酸二水素マグネシウムを $4 \mathrm{wt} \%$ 添加した配合物（Va 7 と $\mathrm{Va} 15)$ の $800^{\circ} \mathrm{C}$ 焼成試料について測定した平均 温度と熱伝導率との関係を図-8 亿示す.

測定温度範囲内では, 熱伝導率は平均温度とともにす べて直線的に変化する。また，それぞれの基礎組成をも つ配合物に燐酸やオルト燐酸二水素マグネシウムを添加 した場合，熱伝導率がやや減少する傾向がある。これは 嵩密度の減少の傾向と対応しており, 焼成時における添 加剂の脱水反応がマトリックスの多孔性を増大させた結 果であると考えられる。

\section{4. 総 括}

膨脹蛭石一粘土系断熱材に, 燐酸および燐酸塩を添加 した場合の圧縮強さなどの諸性質におよぼす影響と，X

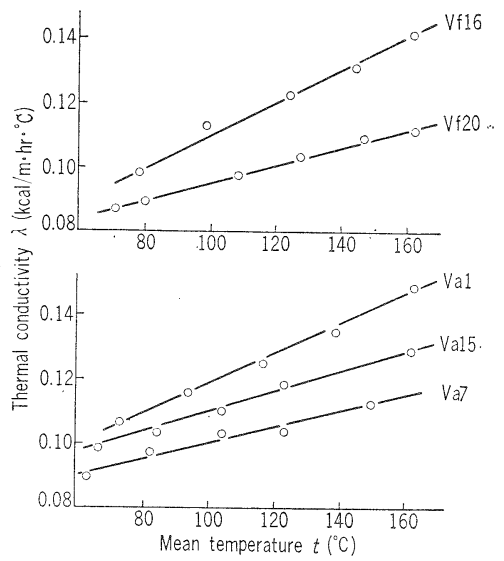

$\begin{array}{cc}\text { Specimen No. } & \text { Bulk density }\left(\mathrm{g} / \mathrm{cm}^{3}\right) \\ \text { Vf } 16 & 0.57 \\ \text { Vf } 20 & 0.45 \\ \text { Va } 1 & 0.52 \\ \text { Va } 15 & 0.46 \\ \text { Va } 7 & 0.37\end{array}$

Fig. 8. Relation between thermal conductivity and mean temperature for heat insulators in the expanded vermiculite-bond clay-additive system. The composition of each specimen number was shown in Table 1.

線回折で確認された結晶相との関連について検討した。 得られた結論はつぎの通りである。

1）福島県産や南アフリカ産の膨脹蛭石, 蝉石掞よび 木節粘土と, 燐酸, オルト燐酸二水素アルミニウムおよ びオルト燐酸二水素マグネシウムとの焼成試料 $\left(800^{\circ}\right.$ $1000^{\circ} \mathrm{C}$ ) をX線回折法でしらべた結果，オルト燐酸マグ ネシウム, オルト燐酸アルミニウムおよびピロ粼酸マグ ネシウムの結晶相が生成することを認めた。これは，添 加剂と原料中の酸化物成分との間に反応が抗こっている と考えられ，また，それは原料粒子の界面に打ける固相 反応としておこっているといえる。

2）膨脹蛭石や粘土類と燐酸との 2 成分混合系焼成試 料の吸湿性や $\mathrm{pH}$ 測定の結果によると, 混合系中の約 $10 \mathrm{wt} \%$ までの粼酸のほとんどがオルト燐酸マグネシウ ムやオルト燐酸アルミニウムの結晶の生成に消費されて いる。

3) 膨脹蛭石 (10 20 mesh/in) 一粘土系断熱材に燐酸 や燐酸塩を添加した場合, オルト燐酸二水素マグネシウ ムを添加した試料については, その添加量の増加ととも に圧縮強さの増大寸る傾向がすべての試料汇認められ た.これは，添加剤が蛭石骨材および粘土結合材中の金 属酸化物成分と反応して, $\mathrm{MgO}-\mathrm{P}_{2} \mathrm{O}_{5}$ 系や $\mathrm{Al}_{2} \mathrm{O}_{3}-\mathrm{P}_{2} \mathrm{O}_{5}$ 系の結晶をマトリックス中に生成し，それが骨材と結合 材の両者の界面において接着層を形成することによっ て, そのマトリックスの圧縮強さを増大させる効果を与 えたと考光られる。 
4）膨脹蛭石一粘土系断熱材に燐酸やオルト燐酸二水 素マグネシウムを添加した場合, 熱伝導率がやや減少す る傾向がある。これは嵩密度の減少の傾向と対応してお り，燒成時における添加剤の脱水反応がマトリックスの 多孔性を增大させた結果であると考えられる。

\section{文献}

1) F.K. Pence, E.B. Blount, J. Am. Ceram. Soc. 27, 50 (1944).

2) R.F. Rea, Am. Ceram. Soc. Bull. 26, 36 (1947).

3) J. Hitner, Am. Ceram. Soc. Bull. 35, 147 (1956).

4) A.J. Gitter, Refractories J. 34, 435 (1958).

5) G.C. Robinson, J. Am. Ceram. Soc. 41, 74 (1958).
6）椿隆行 · 田中雅美 ·上池 修, 窝協 73, 111-17(1965)。

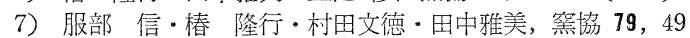
-55 (1971).

8）田中雅美 - 㦈 隆行 - 植嶋稔郎 - 上池 修, 䉑協 64, 8389 (1956).

9) W.H. Gitzen, L.D. Hart, G. Maczura, Am. Ceram. Soc. Bull. 35, 217 (1956).

10) J.E. Lyon, T.U. Fox, J.W. Lyons, Am. Ceram. Soc. Bull. 45, 1078 (1966).

11) 深津良樹, 大阪府立大学大学院工学研究科修士論文, (19 68).

12）塩田政利・加藤泰三・沼田秀二，昍硝子研究報告 16,89 (1966).

(7/15/1971 受付) 